\title{
PENGEMBANGAN MEDIA INTERAKTIF MENGGUNAKAN MODEL ASSURE UNTUK MEMBANTU GURU DALAM PEMBELAJARAN FISIKA TENTANG ALAT UKUR LISTRIK
}

\author{
Puguh Santoso Pengawas SMA \\ Cabang Dinas Pendidikan Wilayah Kabupaten dan Kota Blitar \\ E-mail: puguh.blitar@gmail.com
}

\begin{tabular}{l}
\hline Tersedia Online di \\
\hline http://www.jurnal.unublitar.ac.id/ \\
index.php/briliant \\
\hline Sejarah Artikel \\
\hline Diterima pada 13 Mei 2019 \\
Disetuji pada 16 Mei 2019 \\
Dipublikasikan pada 22 Mei 2019 \\
Hal. 235-248 \\
\hline Kata Kunci: \\
\hline Alat Ukur Listrik, Model Assure, \\
Media Interaktif \\
\hline
\end{tabular}

\begin{tabular}{l}
\hline Tersedia Online di \\
\hline http://www.jurnal.unublitar.ac.id/ \\
index.php/briliant \\
\hline Sejarah Artikel \\
\hline Diterima pada 13 Mei 2019 \\
Disetuji pada 16 Mei 2019 \\
Dipublikasikan pada 22 Mei 2019 \\
Hal. 235-248 \\
\hline Kata Kunci: \\
\hline Alat Ukur Listrik, Model Assure, \\
Media Interaktif \\
\hline
\end{tabular}

DOI:

http://dx.doi.org/10.28926/briliant .v3i4.319

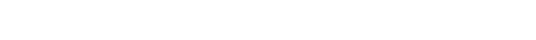

\begin{abstract}
Abstrak: Penelitian ini merupakan penelitian pengembangan, yang mengacu pada model Borg and Gall dengan tujuan membantu guru Fisika dalam mengembangkan media pembelajaran interaktif melalui forum MGMP Fisika SMA Kabupaten Blitar. Media interaktif berupa rangkaian presentasi berisi rumus dan gambar. Data yang dihimpun didasarkan pada: (1) Deskripsi tanggapan ahli isi/materi; (2) Deskripsi tanggapan ahli media; (3) Pengamatan oleh 4 orang guru terhadap aktivitas siswa; (4) Deskripsi Pengamatan media hasil pengembangan penulis oleh guru yang secara langsung mengamati media ini dan (5) Deskripsi tanggapan siswa terhadap penggunaan media ini guna dikembangkan pada pokok bahasan lainnya. Selain itu juga digunakan nilai hasil ulangan harian sebelum menggunakan media interaktif sebagai pretest dan nilai ujicoba menggunakan media interaktif sebagai postest yang kemudian dibandingkan untuk mengetahui ada atau tidaknya pengaruh setelah menggunakan media interaktif ini. Dalam penelitian ini menggunakan software Microsoft power point untuk menyajikan materi "Alat
\end{abstract} Ukur Listrik" yang dikemas dalam bentuk media interaktif dengan menggunakan model pembelajaran Assure. Hasil akhir dari penelitian pengembangan ini adalah berupa fakta kenaikan perolehan nilai sebesar $11,13 \%$ dari sebelumnya.

\section{PENDAHULUAN}

Pelajaran Fisika merupakan pelajaran yang menuntut banyak ketrampilan praktek dan ketelitian menghitung. Dalam pembelajaran Fisika hampir selalu disuguhkan rumus-rumus, konstanta, tabel, koefisien dan lain-lain yang hal ini bisa menjadikan siswa menjadi cepat merasa bosan. Oleh karena itu perlu adanya suatu hal baru bagi siswa agar kebosanan tersebut dapat dihindarkan.

Dengan berbekal sebuah Laptop yang dilengkapi dengan software Microsoft Power Point dan ditunjang dengan jaringan internet, guru dapat menyuguhkan pembelajaran yang bisa membuat siswa merasa mendapatkan hal baru yang tentunya akan membuat siswa menjadi senang, nyaman dan kerasan dalam belajar.

Sebagai Pengawas SMA di Kabupaten dan Kota Blitar, melalui kegiatan MGMP Fisika SMA Kabupaten Blitar penulis ingin membantu guru dalam mengembangkan model pembelajaran yang selama ini kurang diperhatikan oleh guru-guru SMA Negeri di Kabupaten Blitar yaitu memodifikasi metode mengajar dari model ceramah dengan memanfaatkan 
diskusi kelompok yang aktif serta melakukan praktikum di laboratorium Fisika, menjadi model seperti tersebut diatas ditambah penggunaan media interaktif dengan model pembelajaran Assure yang dikemas dalam bentuk media interaktif dengan bantuan software Microsoft Power Point.

Dari kondisi Pembelajaran Fisika di SMA Negeri se Kabupaten Blitar seperti diatas, maka pengembangan media interaktif seperti ini ditengarai sangat menunjang proses belajar siswa, namun dalam penembangannya masih ada beberapa hal yang mengganjal yaitu: 1). Apakah dengan mengembangkan media pembelajaran dengan model Assure pada mata pelajaran fisika, perolehan nilai siswa dapat ditingkatkan?; 2). Setelah menggunakan media pembelajaran Interaktif dengan model pembelajaran Assure dalam mata pelajaran fisika ini, seberapa besarkah peningkatan hasil pencapaian nilai siswa dibandingkan dengan sebelumnya?; 3). Bagaimanakah tanggapan siswa terhadap media membelajaran interaktif dengan model pembelajaran Assure dalam mata pelajaran Fisika jika dikembangkan pada materi yang lainnya?

Sehubungan dengan permasalahan di atas, tujuan penelitian pengembangan ini adalah untuk mengembangkan media pembelajaran interaktif menggunakan model Assure pada siswa kelas X. IPA di SMA Negeri se Kabupaten Blitar melalui diskripsi dari beberapa ahli/guru senior dengan rincian: 1). Mendiskripsikan tanggapan/pendapat dari ahli isi/materi tentang kelayakan isi/materi yang disajikan; (2) Mendiskripsikan tanggapan/ pendapat dari ahli media pembelajaran tentang kelayakan media interaktif ini untuk dikembangkan; (3) Mendiskripsikan tanggapan/pendapat 4 orang guru dari 4 SMA yang mengampu mata pelajaran Fisika dengan mengamati secara langsung aktivitas siswa saat KBM menggunakan media interaktif ini berkaitan dengan ketertarikan siswa; (4) Mendiskripsikan tanggapan/pendapat 4 orang guru dari 4 SMA yang mengampu mata pelajaran Fisika dengan mengamati secara langsung aktivitas guru saat berlangsungnya KBM dengan menggunakan media interaktif ini berkaitan dengan keluasan materi yang ditayangkan; (5) Mendiskripsikan tanggapan/pendapan dari siswa saat KBM menggunakan media interaktif ini guna pengembangan lebih lanjut. Selain itu juga memanfaatkan hasil nilai ulangan harian sebelumnya yang dipandang sebagai nilai pretest dan kemudian dibandingkan dengan hasil nilai uji coba media interaktif yang dipandang sebagai nilai postest.

Media merupakan kata yang berasal dari bahasa latin yaitu medius, yang secara harfiah berarti tengah, perantara atau pengantar (Arsyad, Azhar. 2002). Oleh karena itu, media dapat diartikan sebagai perantara atau pengantar pesan dari pengirim ke penerima pesan. Media dapat berupa suatu bahan (software) dan/atau alat (hardware). Kemp, JE. (1985) menggambarkan peranan media dalam komunikasi dengan model alur komunikasi sebagai berikut: 


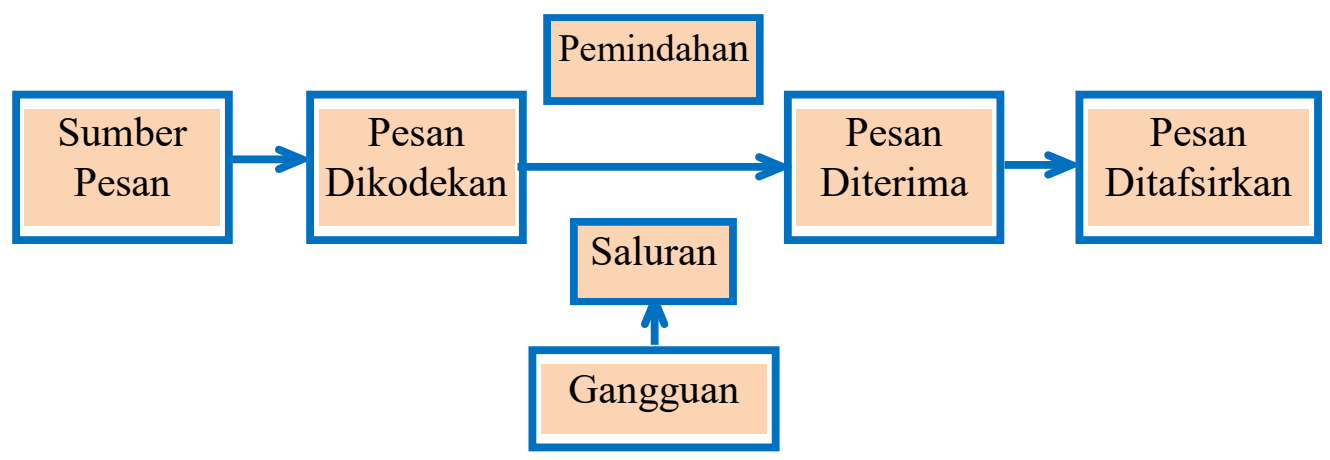

Gambar 1. Model komunikasi J. E. Kemp

Model di atas menjelaskan bahwa dalam semua komunikasi baik sederhana maupun kompleks akan selalu sama urutan proses pemindahan informasinya. Media memungkinkan siswa dapat belajar sesuai dengan kemampuan, minat yang sesuai dengan modul atau pembelajaran berprogram yang dapat mempercepat kemampuan belajar masing-masing (Degeng, Sudana. 2005)

Multimedia interaktif merupakan media yang dapat digunakan dalam memperjelas proses pembelajaran apabila didukung oleh media pembelajaran yang dapat menarik minat dan perhatian siswa sehingga mampu menyediakan lingkungan belajar yang adaptif dan variatif, sehingga siswa dapat mengontrol dan menentukan sendiri urutan materi pembelajaran sesuai dengan yang diinginkan. Multimedia interaktif dalam pembelajaran dapat menghasilkan suatu pembelajaran yang efektif dengan menggabungkan barbagai komponen (teks, garfik, audio, video/animasi) dan dengan menggunakan computer/laptop dapat mengilustrasikan sebuah konsep melalui animasi, bunyi, dan demonstrasi menarik yang memungkinkan siswa untuk memperoleh kemajuan sesuai dengan tingkat kemampuannya masing-masing (Bintas, J. \& Gelibolu, M. F. 2010).

Menurut Gagne, M. R, dkk (1992), multimedia interaktif yang diperkaya dengan materi dalam format audio visual akan dapat merangsang siswa untuk belajar dengan menerapkan tiga prinsip pembelajaran Contiguity (menghadirkan rangsangan situasi bersamaan dengan respon yang diinginkan), Repetition (penggulangan) dan Reinforcement (penguatan).

Fisika merupakan salah mata pelajaran yang masuk dalam lingkup program IPA. Dalam mata pelajaran ini dipelajari tentang hal-hal yang berkaitan dengan kejadian-kejadian alam secara fisik. Oleh karena itu diperlukan peralatan dan bahan dalam Laboratorium Fisika, tetapi hal itu sangatlah terbatas sehingga diperlukan suatu metode lain guna memperjelas dalam mempelajari fenomena alam. Sedangkan alat ukur merupakan suatu hal yang sangat penting dalam pelajaran fisika, karena alat ukur merupakan sesuatu yang digunakan untuk mendapatkan data.

Alat ukur listrik adalah bagian dari alat ukur dalam Fisika yang khusus digunakan untuk mendapatkan data mengenai besaran-besaran listrik seperti kuat arus listrik, tegangan listrik, hambatan listrik dan sebagainya. Pembelajaran model Assure adalah salah satu petunjuk yang bisa membantu untuk merencanakan, mengidentifikasi, menentukan tujuan, memilih metode dan bahan, serta evaluasi. Model Assure ini disarankan untuk guru dalam membelajarkan siswa dalam pembelajaran yang direncanakan dan disusun secara 
sistematis dengan mengintegrasikan teknologi dan media pembelajaran sehingga pembelajaran tersebut menjadi lebih efektif dan menyenangkan serta banyak bermakna bagi siswa. Pembelajaran dengan model Assure mempunyai beberapa tahapan yang dapat membantu terwujudnya pembelajaran yang efektif dan bermakan bagi peserta didik.

Menurut Smaldino, S. E, dkk (2008), tahapan-tahapan penjabaran dari model pembelajaran Assure, adalah sebagai berikut:

1. Analyze Learner (Analisis Pembelajar)

Tujuan utama dalam analisa, adalah menemukan kebutuhan belajar siswa sehingga mereka mampu mendapatkan tingkatan pengetahuan dalam pembelajaran secara maksimal.

2. State Standards and Objectives (Menentukan Standard Dan Tujuan)

Tahap selanjutnya dalam model pembelajaran Assure adalah merumuskan tujuan dan standar. Dengan demikian diharapkan siswa dapat memperoleh suatu kemampuan dan kompetensi tertentu dari pembelajaran.

3. Selct Strategies Technology, Media, and Materials (Memilih, Strategi, Teknologi, Media dan Bahan ajar)

Langkah selanjutnya dalam membuat pembelajaran yang efektif adalah mendukung pembelajaran dengan menggunakan teknologi dan media dalam sistematika pemilihan strategi, teknologi dan media serta bahan ajar

4. Utilize Technology, Media and Materials (Menggunakan Teknologi, Media dan Bahan Ajar)

5. Require Learner Participation (Mengembangkan Partisipasi Peserta Didik)

Tujuan utama dari pembelajaran adalah adanya partisipasi siswa terhadap materi dan media yang ditampilkan oleh guru. Seorang guru pada era teknologi seperti sekarang ini dituntut untuk memiliki pengalaman dan praktik seperti menerapkan, menganalisis, mensintesis, dan mengevaluasi dari pada sekedar memahami dan memberi informasi kepada siswa. Hal ini sejalan dengan gagasan konstruktivistik bahwa belajar merupakan proses mental aktif yang dibangun berdasarkan pengalaman yang autentik, dimana para siswa akan menerima umpan balik informative untuk mencapai tujuan mereka dalam belajar.

Model pembelajaran Assure sangat membantu dalam merancang program dengan menggunakan berbagai jenis media. Manfaat dari model Assure adalah:

1. Sederhana, sehingga dapat dikembangkan sendiri oleh guru.

2. Komponen KBM (Kegiatan Belajar Mengajar) lengkap.

3. Siswa dapat dilibatkan dalam persiapan untuk KBM.

\section{METODE PENELITIAN}

Penelitian ini dilakukan pada 4 SMA Negeri di wilayah Kabupaten Blitar pada semester 1 (Ganjil) tahun pelajaran 2017/2018 dengan mengambil sampel untuk uji coba media interaktif alat ukur listrik pada siswa Kelas X. IPA di SMA Negeri 1 Garum Kabupaten Blitar.

Dalam penelitian pengembangan ini digunakan model Research and Development (Gall, M. D., dkk, 2003) yang didalamnya terdapat 10 tahap pelaksanaan sebagai berikut:

1. Research and information collecting (Penelitian dan mengumpulkan informasi)

2. Planning (Perencanaan)

3. Develop preliminary form of product (Mengembangkan format produk awal) 
4. Preliminary field testing (Uji lapangan awal)

5. Main product revision (Revisi produk utama)

6. Main field testing (Uji lapangan utama)

7. Operational product revision (Revisi produk operasional)

8. Operational field testing (Uji operasional lapangan)

9. Final product revision (Revisi produk akhir)

10. Dissemination and implementation (Penyebaran dan implementasi)

Tahapan penelitian tersebut digambarkan seperti berikut:

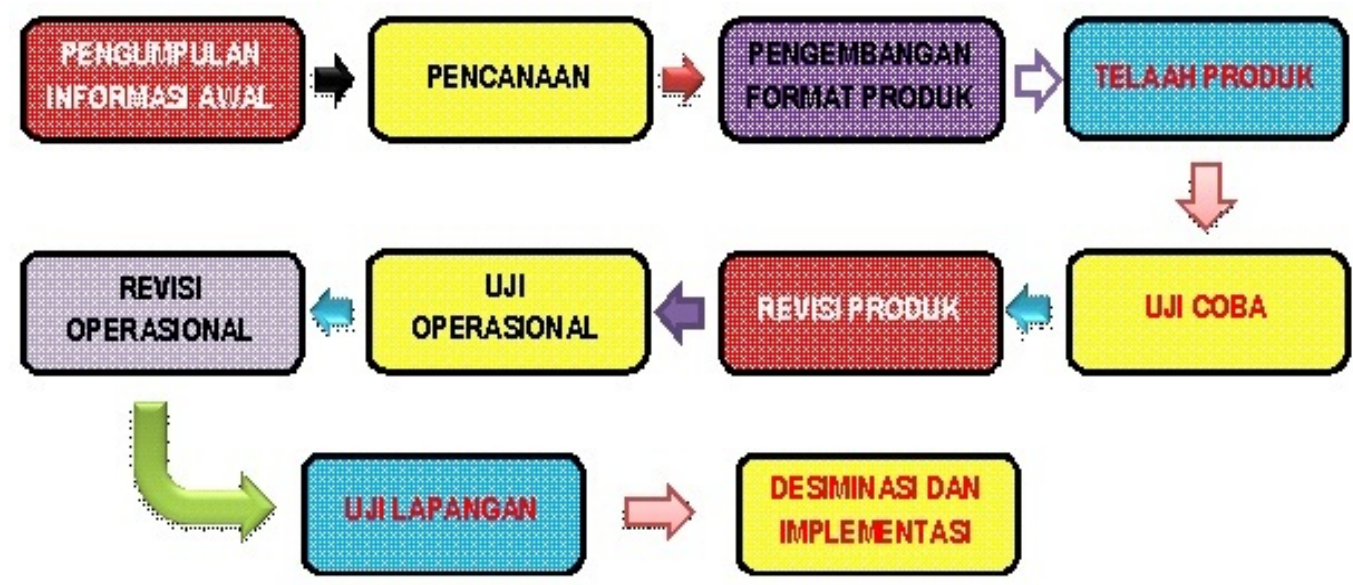

Gambar 2. Tahapan pengembangan menurut Borg \& Gall (1983)

Pengembangan media interaktif alat ukur listrik dalam penelitian pengembangan ini akan dijelaskan sebagai berikut:

1. Tahap penelitian dan pengumpulan informasi termasuk kajian pustaka, observasi kelas, dan penyusunan laporan.

Pada tahap ini dilakukan pengumpulan informasi dan kajian pustaka yang berkaitan dengan pembangunan media interaktif alat ukur listrik. Pengumpulan informasi awal dilakukan dengan memperhatikan hasil evaluasi siswa pada kompetensi dasar pengukuran besaran-besaran listrik pada pembelajaran sebelumnya berdasarkan daftar nilai, bahwa rata-rata nilai ulangan harian fisika untuk 2 (dua) kelas pada semester 1 (Ganjil) tahun sebelumnya adalah 68,73.

2. Dalam tahap perencanaan ini, digunakan unsur-unsur yang ada pada prosedur Kemp dkk. (1994), dengan urutan langkah unsur yang terdapat pada prosedur diatas diuraikan sebagai berikut:

a. Analisis Tujuan (Instructional Problems)

Tujuan analisis ini untuk menetapkan arah dasar yang dibutuhkan dalam pengembangan media interaktif alat ukur listrik. Dari arah dasar ini disusun alternatif pembelajaran yang sesuai menurut aspek Kurikulum Tingkat Satuan Pendidikan (KTSP). Menurut KTSP disebutkan bahwa tujuan pendidikan Fisika adalah untuk membekali siswa dengan kemampuan berpikir logis, analitis, sistematis, kritis dan kreatif serta berkemampuan kerjasama yang baik dengan kriteria sebagai berikut:

1) Memahami konsep Fisika, menjelaskan keterkaitan antar konsep dan mengaplikasikan konsep atau algoritma, secara luwes, akurat, efisien dan tepat dalam pemecahan masalah. 
2) Menggunakan penalaran pola dan sikap, melakukan manipulasi fisika dalam membuat generalisasi, menyusun bukti atau menjelaskan gagasan dan pernyataan secara fisis.

3) Mengkomunikasikan ide melalui simbul, tabel, diagram, atau media lain untuk menjelaskan permasalahan.

4) Memiliki sikap menghargai manfaat fisika dalam kehidupan seharihari, misalnya mempunyai rasa keingintahuan yang tinggi, perhatian dan minat yang tinggi dalam mempelajari fisika.

Kompetensi dasar yang dikembangkan bahan pembelajarannya dalam penelitian ini adalah penggunaan alat-alat ukur listrik pada kelas X. IPA semester 1 (ganjil).

b. Analisis Karakteristik Siswa (Learner Characteristics)

Analisis siswa merupakan cara mengetahui karakteristik siswa yang meliputi tingkat perkembangan kognitif, kemampuan berikir, latar belakang pengetahuan, dan latar belakang sosial budaya siswa. Dari hasil analisis ini nantinya akan dijadikan acuan dalam menyusun materi pembelajaran.

Dalam penelitian ini, yang menjadi subjek adalah siswa kelas X, IPA pada jenjang pendidikan SMA.

c. Analisis Tugas (Task Analysis)

Analisis tugas merupakan pemahaman tugas dalam pembelajaran yang dilakukan dengan mengidentifikasi struktur kompetensi dasar yang dipilih, yaitu penggunaan alat-alat ukur listrik

d. Tujuan Pembelajaran (Instructional Objectives)

Tujuan pembelajaran khusus disusun dengan berpedoman pada silabus Fisika yang merupakan dasar untuk mendesain perangkat pembelajaran dan menyusun evaluasi.

e. Rangkaian Isi (Content Sequencing)

Rangkaian isi mendeskripsikan analisis isi, analisis konsep dan menentukan urutan konsep. Hasil akhir dari rangkaian isi tertuang dalam materi ajar dan Lembar Kegiatan Siswa (LKS) sebagai perangkat pembelajaran yang akan digunakan dalam penelitian.

f. Strategi Pembelajaran (Instructional Strategies)

Sesuai dengan inti penelitian ini adalah mengembangkan perangkat pembelajaran yang berorientasi model pembelajaran Assure pada kompetensi dasar menggunakan alat ukur listrik, strategi pembelajaran yang dipersiapkan adalah dengan metode presentasi, ceramah dan diskusi. Sedangkan pendekatan yang digunakan adalah pendekatan secara kelompok.

g. Pemberian Pembelajaran (Instructional Delivery)

Kegiatan pemilihan dan sumber belajar disesuaikan dengan hasil analisis tugas, karakteristik siswa, dan ketersediaan alat dan bahan seperti LCD proyektor, komputer atau laptop, speaker active yang ada di SMA Negeri 1 Garum Kabupaten Blitar.

h. Alat Evaluasi (Evaluation Instrumens)

Sesuai dengan tujuan penelitian yaitu untuk membuat media interaktif dan mengetahui peningkatan pemahaman tentang Alat Ukur Listrik serta menganalisis tanggapan siswa terhadap penggunaan media interaktif Alat 
Ukur Listrik siswa kelas X. IPA semester 1 (Ganjil) SMA Negeri di Kabupaten Blitar dengan model pembelajaran Assure, maka pada penelitian ini akan dikembangkan dua macam instrumen evaluasi yaitu: 1) instrumen evaluasi untuk mengetahui kualitas proses pembelajaran dan 2) instrumen evaluasi untuk mengetahui hasil belajar.

1) Penyusunan instrumen untuk menilai kualitas proses pembelajaran. Tujuan penyusunan instrumen evaluasi proses yaitu untuk mengetahui gambaran kualitas pembelajaran yang telah dilakukan. Dari kegiatan ini akan dihasilkan instrumen Lembar Observasi untuk mengukur:

a) Aktivitas siswa (Instrumen 1).

b) Aktivitas guru Pengembang (Instrumen 2).

Di sini juga akan dihasilkan angket yaitu: angket untuk mengetahui tanggapan siswa terhadap pembelajaran dengan model pembelajaran Assure, yaitu angket panggapan siswa.

2) Penyusunan instrumen evaluasi untuk megetahui kualitas hasil belajar. Instrumen evaluasi disusun berdasarkan hasil perumusan tujuan pembelajaran khusus. Evaluasi ini digunakan untuk mengukur perubahan tingkah laku pada siswa setelah berlangsung serangkaian proses pembelajaran dalam ranah kognitif, afektif, dan psikomotor.

i. Sumber Perangkat Pembelajaran (Instructional Resources)

Sumber perangkat pembelajaran kompetensi dasar mengukur besaran listrik, yang berpedoman pada silabus Fisika.

3. Mengembangkan format produk awal, berupa media interaktif alat ukur listrik, buku panduan, dan perangkat evaluasi, yang dapat diuji di lapangan, kuesioner dan pedoman wawancara yang digunakan dalam uji lapangan. Dengan demikian, bentuk awal harus mencakup prosedur yang lebih banyak untuk evaluasi yang nantinya akan disertakan dalam produk akhir.

4. Telaah Produk, dilakukan menggunakan tehnik wawancara, data observasi dan kuesioner dikumpulkan dan dianalisis untuk mendapatkan hasil kualitatif dari produk yang dibuat dan evaluasi ini hanya ditekankan pada penilaian kualitatif konten saja.

5. Uji Coba, dilakukan berdasarkan hasil telaah. Apakah produk yang dihasilkan masih perlu direvisi atau tidak dengan mengambil subyek yang sama. Jika tidak langsung dilanjutkan pada langkah berikutnya.

Tujuan dari uji coba ini adalah untuk menentukan apakah produk memenuhi harapan atau tidak.

6. Revisi Produk, hasil uji coba direvisi sehubungan dengan ketidak sesuaian antara tujuan program dibandingkan dengan data nilai sebelumnya.

7. Uji Operasional, untuk mengetahui apakah pada uji coba menunjukkan bahwa produk perlu direvisi lagi atau tidak.

8. Revisi Operasional, hasil wawancara, data observasi dan kuesioner dikumpulkan dan dianalisis, untuk menentukan apakah produk siap digunakan di sekolahsekolah secara mandiri. Untuk itu, paket harus lengkap dan diuji secara menyeluruh. Uji operasional dilakukan di SMA Negeri 1 Garum Kabupaten Blitar.

9. Uji Lapangan, Setelah dilakukan revisi operasional yang didasarkan pada uji operasional dengan lengkap dan data telah dianalisis, maka dilakukan uji yang terakhir, yaitu uji lapangan. 
10. Penyebaran dan Implementasi, penelitian pengembangan merupakan proses yang cukup rumit.

Diseminasi mengacu pada upaya membantu pengguna produk. Dalam hal ini pengembang dapat mendesiminasilkan produk melalui MGMP tingkat Kabupaten atau dengan cara menulis di jurnal.

Data yang diperoleh berupa angka rata-rata atau presentase yang berasal dari data hasil masing-masing instrumen. Data angka dijadikan data deskriptif sesuai dengan kriteria masing-masing. Instrumen yang dibuat meliputi (1) Instrumen 1: Validasi Media oleh Ahli Isi/Materi, (2) Instrumen 2: Validasi Media oleh Ahli desain, (3) Instrumen 3: Pengamatan aktivitas siswa oleh guru, (4) Instrumen 4: Pengamatan aktivitas pengembang oleh guru dan (5) Instrumen 5: Angket untuk tanggapan siswa serta memanfaatkan data nilai ulangan harian sebelum dan sesudah menggunakan media interaktif ini yang hasil nilainya dipandang sebagai nilai pretest dan postes.

Instrumen validasi media baik dari ahli isi/materi maupun ahli desain diadopsi dari Media Pembelajaran (Arsyad, Azhar. 2002). Analisis data dengan menggunakan analisis deskriptif kwantitatif yang berupa rata-rata dan kemudian dibuat persentase, yang akan diuraikan sebagai berikut:

1. Analisis Isi/Materi Pembelajaran

Analisis ini diperoleh dari instrumen Validasi Media oleh ahli isi/materi yang merupakan hasil konsultasi dan pertimbangan dari ahli isi/materi pembelajaran yang dalam hal ini adalah ketua MGMP Fisika SMA Kabupaten Blitar. Hasil analisis ini berupa pengkategorian menurut tingkatan angka 1 sampai 4 yang kemudian dianalisis dengan melihat kwantitas, yakni banyaknya angka kategori tertinggi yang didapat.

2. Analisis Desain Media Pembelajaran

Analisis ini diperoleh dari instrumen Validasi Media oleh ahli media pembelajaran yang merupakan hasil konsultasi dan pertimbangan dari ahli media pembelajaran yang dalam hal ini adalah ketua MGMP Fisika SMA Negeri Kabupaten Blitar. Hasil analisis ini berupa pengkategorian menurut tingkatan angka 1 sampai 4 yang kemudian dianalisis dengan melihat kwantitas, yakni banyaknya angka kategori tertinggi yang didapat.

3. Analisis Data Aktivitas Siswa oleh Guru

Analisis data ini diperoleh dari instrumen pengamatan aktivitas siswa oleh 4 (empat) orang guru yang mengamati kegiatan siswa selama mengikuti pembelajaran. Data hasil pengamatan aktivitas siswa ini hanya berupa jumlah kategori "Ya" dan jumlah kategori "Tidak" yang kemudian dianalisis dengan melihat kwantitas, yakni banyaknya kategori terbanyak rata-rata yang didapat oleh 4 (empat) orang guru pengamat dan selanjutnya dinyatakan dalam prosentase.

4. Analisis Data Pengamatan Aktivitas Pengembang Oleh Guru.

Analisis data ini diperoleh dari instrumen pengamatan aktivitas pengembang oleh 4 (empat) orang guru yang mengamati kegiatan pengembang. Data hasil pengamatan aktivitas pengembang ini juga berupa jumlah kategori "Ya" dan jumlah kategori "Tidak" yang kemudian dianalisis dengan melihat kwantitas, yakni banyaknya kategori terbanyak rata-rata yang didapat oleh 4 (empat) orang guru pengamat dan selanjutnya dinyatakan dalam prosentase.

5. Analisis Data Tanggapan Siswa. 
Data tanggapan siswa dianalisis dengan persentase, yaitu jumlah siswa yang memberikan tanggapan sama dibagi dengan jumlah siswa seluruhnya kemudian dikalikan dengan $100 \%$.

6. Analisis Data Hasil Evaluasi Belajar Siswa

Data hasil belajar siswa berupa nilai pretest (nilai ulangan harian) dan nilai postest (nilai ulangan uji coba media interaktif)

Analisis data hasil belajar siswa digunakan untuk mengetahui hasil belajar siswa melalui implementasi uji produk dalam proses pembelajaran dengan cara membandingkan nilai hasil pretest dengan nilai hasil postest.

Penggunaan media interaktif ini dikatakan memenuhi harapan jika hasil nilai postest lebih baik dari nilai pretest

\section{HASIL DAN PEMBAHASAN}

Data yang diperoleh dalam penelitian ini berupa data hasil pengembangan Media Interaktif Fisika Alat Ukur Listrik, menggunakan model Assure pada siswa kelas X.IPA SMA Negeri di Kabupaten Blitar semester 1 (Ganjil) tahun pelajaran 2017/2018 yang berupa data:

1. Data Validasi Media Oleh Ahli Isi/Materi

Secara umum, gambaran yang disampaikan oleh oleh Ahli Isi/Materi tentang media interaktif ini melalui Validasi Media Oleh Ahli Isi/Materi adalah seperti Tabel 1

Tabel 1. Hasil Validasi Media oleh Ahli Isi/Materi

\begin{tabular}{|c|c|c|c|c|}
\hline No. Item & $\begin{array}{c}\text { Sangat } \\
\text { Baik (4) }\end{array}$ & $\begin{array}{c}\text { Baik } \\
\text { (3) }\end{array}$ & $\begin{array}{c}\text { Cukup } \\
\text { (2) }\end{array}$ & $\begin{array}{c}\text { Kurang } \\
\text { (1) }\end{array}$ \\
\hline 1 & $\sqrt{ }$ & & 0 & 0 \\
\hline 2 & & $\sqrt{ }$ & & \\
\hline 3 & $\sqrt{ }$ & & & \\
\hline 4 & $\sqrt{ }$ & & & \\
\hline 5 & & $\sqrt{ }$ & & \\
\hline 6 & $\sqrt{ }$ & & & \\
\hline 7 & & $\sqrt{ }$ & & \\
\hline 8 & $\sqrt{ }$ & & & \\
\hline 9 & & $\sqrt{ }$ & & \\
\hline 10 & $\sqrt{ }$ & & & \\
\hline Jumlah & 6 & 4 & 0 & 0 \\
\hline Prosentase & $60 \%$ & $40 \%$ & $0 \%$ & $0 \%$ \\
\hline
\end{tabular}

Sumber : Hasil angket

Dari tabel 1 di atas didapat hasil: sangat baik (4) $=6$ tanggapan dari 10 item tanggapan (60\%); baik (3) = 4 tanggapan dari 10 item tanggapan $(40 \%)$ dan lainnya adalah $0(0 \%)$.

Dengan demikian hasil validasi media oleh Ahli Isi/Materi dapat dinyatakan baik dan layak digunakan sebagai media interaktif Fisika Alat Ukur Listrik untuk siswa SMA Kelas X.IPA

2. Data Hasil Validasi Media Oleh Ahli Desain

Secara umum, gambaran yang disampaikan oleh hhli desain tentang media interaktif ini melalui Validasi Media Oleh Ahli Desain adalah seperti tabel 2 berikut:

Tabel 2. Hasil Validasi Media Oleh Ahli Desain 


\begin{tabular}{|c|c|c|c|c|}
\hline No. Item & $\begin{array}{c}\text { Sangat } \\
\text { Baik (4) }\end{array}$ & $\begin{array}{c}\text { Baik } \\
(3)\end{array}$ & $\begin{array}{c}\text { Cukup } \\
(2)\end{array}$ & $\begin{array}{c}\text { Kurang } \\
(1)\end{array}$ \\
\hline 1 & $\sqrt{ }$ & & 0 & 0 \\
\hline 2 & & $\sqrt{ }$ & & \\
\hline 3 & & $\sqrt{ }$ & & \\
\hline 4 & & $\sqrt{ }$ & & \\
\hline 5 & & $\sqrt{ }$ & & \\
\hline 6 & $\sqrt{ }$ & $\sqrt{ }$ & & \\
\hline 7 & $\sqrt{ }$ & & & \\
\hline 8 & $\sqrt{ }$ & & & \\
\hline 9 & & & $\sqrt{ }$ & \\
\hline 10 & $\sqrt{ }$ & $\sqrt{ }$ & & \\
\hline 11 & & 6 & 3 & 0 \\
\hline 12 & & $46,15 \%$ & $23,08 \%$ & $0 \%$ \\
\hline 13 & & & & \\
\hline Jumlah & 4 & & & \\
\hline Prosentase & $30,77 \%$ & 47 & & \\
\hline
\end{tabular}

Sumber : Hasil angket

Dari tabel 2 diatas didapat hasil: sangat baik (4) = 4 tanggapan dari 13 item tanggapan $(30,77 \%)$; baik $(3)=6$ tanggapan dari 13 item tanggapan $(46,15$ $\%$ ); cukup (2) = 3 tanggapan dari 13 item tanggapan $(23,08 \%)$ dan lainnya adalah $0(0 \%)$.

Dengan demikian hasil validasi media oleh Ahli Desain dapat dinyatakan baik dan layak digunakan sebagai media interaktif Fisika Alat Ukur Listri untuk siswa SMA kelas X.IPA.

3. Data Hasil Pengamatan Aktivitas siswa Oleh Guru

Secara umum, gambaran yang disampaikan oleh 4 (empat) orang guru pengamat tentang aktivitas siswa selama proses pembelajaran adalah seperti pada tabel 3 berikut:

Tabel 3. Hasil Angket Pengamatan Aktivitas Siswa

\begin{tabular}{|c|c|c|c|c|c|}
\hline \multirow{2}{*}{ KELAS } & \multirow{2}{*}{$\begin{array}{c}\text { JUMLAH } \\
\end{array}$} & \multicolumn{2}{|c|}{ PERNYATAAN } & PROSENTASE & PROSENTASE \\
\cline { 3 - 4 } & "YA" & "TIDAK" & "YA" & "TIDAK" \\
\hline X.IPA.1 & 32 & 30 & 2 & $100,00 \%$ & $0 \%$ \\
\hline X.IPA.2 & 32 & 28 & 4 & $93,75 \%$ & $6,25 \%$ \\
\hline JUMLAH & 64 & 58 & 6 & $193,75 \%$ & $6,25 \%$ \\
\hline RATA $^{2}$ & 32 & 28 & 3 & $96,88 \%$ & $3,12 \%$ \\
\hline
\end{tabular}

Sumber : Hasil angket

Dari tabel 3 diatas didapat hasil tanggapan oleh siswa dengan pernyataan "YA" $=58$ tanggapan dari 64 siswa $(96,88 \%)$ dan "TIDAK" = 6 tanggapan dari 64 siswa $(3,12 \%)$.

Dengan demikian hasil tanggapan oleh siswa dengan pernyataan "YA" $=96,88$ $\%$ yang sangat jauh jika dibandingkan dengan pernyataan "TIDAK" yang hanya 3,12\%, sehingga media ini dapat dinyatakan baik dan layak digunakan sebagai media interaktif Fisika Alat Ukur Listri untuk siswa SMA kelas X.IPA.

4. Data Pengamatan Aktivitas Pengembang Oleh Guru

Secara umum, gambaran yang disampaikan oleh 4 (empat) guru tentang aktivitas pengembang dalam menggunakan media interaktif ini adalah semua memberikan pernyataan "Ya" yang berarti prosentasi pilihan pernyataan "Ya" adalah $100 \%$, sehingga Media ini dapat dinyatakan baik dan layak digunakan 
sebagai Media Interaktif Fisika Alat Ukur Listri untuk siswa SMA kelas X.IPA.

5. Data Hasil Angket Tanggapan Siswa

Secara umum, tanggapan yang diberikan oleh siswa terhadap kegiatan pembelajaran dengan menggunakan media interaktif ini adalah seperti Tabel 4 berikut:

Tabel 4. Hasil Angket Tanggapan 64 Siswa Tentang Kesesuaian Media

\begin{tabular}{|c|c|c|c|c|c|}
\hline No. Item & $\begin{array}{c}\text { Sangat Sesuai } \\
(4)\end{array}$ & $\begin{array}{c}\text { Sesuai } \\
(3)\end{array}$ & $\begin{array}{c}\text { Cukup Sesuai } \\
(2)\end{array}$ & Tidak Sesuai (1) & Jumlah \\
\hline 1 & 44 & 18 & 2 & 0 & 64 \\
\hline 2 & 44 & 16 & 4 & 0 & 64 \\
\hline 3 & 46 & 16 & 2 & 0 & 64 \\
\hline 4 & 41 & 21 & 2 & 0 & 64 \\
\hline 5 & 44 & 19 & 1 & 0 & 64 \\
\hline 6 & 45 & 16 & 3 & 0 & 64 \\
\hline 7 & 45 & 17 & 2 & 0 & 64 \\
\hline 8 & 48 & 13 & 3 & & 64 \\
\hline 9 & 44 & 21 & 19 & 1 & 85 \\
\hline 10 & 44 & 17 & 3 & 0 & 64 \\
\hline Jumlah & 445 & 174 & 41 & 1 & 661 \\
\hline Rata & 44,5 & 17,4 & 4,1 & 0,1 & 66,1 \\
\hline Prosentase & $67,32 \%$ & $26,32 \%$ & $6,20 \%$ & $0,15 \%$ & $100 \%$ \\
\hline Sur
\end{tabular}

Sumber : Hasil angket

Dari tabel 4 di atas didapat hasil tanggapan rata-rata oleh 64 siswa dengan sangat sesuai $(4)=44,5$ tanggapan dari 64 siswa $(67,32 \%)$; sesuai $(3)=17,4$ tanggapan dari 64 siswa $(26,32 \%)$; cukup sesuai $(2)=4,1$ tanggapan dari 64 siswa $(6,20 \%)$; tidak sesuai $(1)=0,1$ tanggapan dari 64 siswa $(0,15)$.

Dengan demikian hasil tanggapan oleh siswa dengan pernyataan sangat sesuai dan sesuai $(67,32 \%$ dan $26,32 \%$ yang jauh dibanding bdengan pernyataan cukup sesuai dan tidak sesuai $(6,20 \%$ dan $0,15 \%)$, sehingga media ini dapat dinyatakan baik dan layak digunakan sebagai media interaktif Fisika Alat Ukur Listrik untuk siswa SMA kelas X.IPA.

6. Analisis Data Hasil Evaluasi Belajar Siswa

Data hasil belajar siswa berupa nilai pretest (nilai ulangan harian) dan nilai postest (nilai ulangan uji coba media interaktif)

Analisis data hasil belajar siswa digunakan untuk mengetahui hasil belajar siswa melalui implementasi uji produk dalam proses pembelajaran dengan cara membandingkan nilai hasil pre test dengan nilai hasil post test. Penggunaan media interaktif ini dikatakan memenuhi harapan jika hasil nilai postest lebih baik dari nilai pretest. 
Hasil ulangan harian dan hasil post test (hasil uji penggunaan media) adalah seperti Tabel 5 berikut:

Tabel 5 Hasil Evaluasi Belajar Siswa

\begin{tabular}{|c|c|c|c|c|}
\hline \multirow{2}{*}{ No. } & \multirow{2}{*}{ Kelas } & \multirow{2}{*}{$\begin{array}{c}\text { Jumlah } \\
\text { Siswa }\end{array}$} & $\begin{array}{c}|c| \\
\text { Rata }{ }^{2} \text { Ulangan } \\
\text { Hariah }\end{array}$ & Rata $^{2}$ Post Test \\
\hline 1 & & & 68,44 & 78,38 \\
\hline 3 & X. IPA.1 & 32 & 67,88 & 80,20 \\
\hline \multicolumn{2}{c}{ Jumlah } & 32 & 136,32 & 158,58 \\
\hline \multicolumn{2}{c}{ Rata } & 32 & 68,16 & 79,29 \\
\hline \multicolumn{2}{c}{ Prosentase } & $100,00 \%$ & $68,16 \%$ & $79,29 \%$ \\
\hline
\end{tabular}

Sumber : Hasil angket

Dari tabel 5 di atas didapat hasil prosentase nilai rata-rata ulangan harian dari 64 siswa adalah 68,16\% sedangkan prosentase nilai rata-rata post test dari 64 siswa adalah 79,29\%, sehingga ada peningkatan sebesar 68,16\% $79,29 \%=11,13 \%$. Dengan demikian maka Media Interaktif ini dapat dinyatakan baik dan layak digunakan sebagai Media Interaktif Fisika Alat Ukur Listrik untuk siswa SMA kelas X.IPA.

\section{KESIMPULAN}

Berdasarkan hasil yang dipaparkan melalui 5 tabel di atas, maka dapat ditarik kesimpulan berikut:

1. Media Interaktif Fisika Alat Ukur Listrik menggunakan model Assure, yang saya kembangkan ternyata mampu meningkatkan prestasi siswa, khususnya siswa kelas X.IPA.1 dan X.IPA.2 SMAN 1 Garum Kabupaten Blitar yang digunakan sebagai uji coba.

2. Media Interaktif Fisika Alat Ukur Listrik menggunakan model Assure, yang saya kembangkan ternyata mampu meningkatkan perolehan nilai siswa sebesar 11,13 \%, khususnya siswa kelas X.IPA.1 dan X.IPA. 2 SMAN 1 Garum Kabupaten Blitar.

3. Media Interaktif Fisika Alat Ukur Listrik Menggunakan model Assure, yang saya kembangkan ternyata sangat menarik perhatian guru-guru Fisika dan siswa kelas X.IPA.1 dan X.IPA. 2 SMAN 1 Garum Kabupaten Blitar dan mendapat tanggapan yang positif dari Ahli Isi/Materi, Ahli Media Pembelajaran, guru dan siswa untuk dikembangkan lebih lanjut.

4. Menurut para guru pengajar Fisika Kelas X.IPA SMA lainnya di Kabupaten Blitar Media Interaktif Fisika Alat Ukur Listrik Menggunakan Model Assure yang saya kembangkan ternyata juga sangat menarik perhatian siswa di sekolahnya dan mendapat tanggapan yang positif dari siswa untuk dikembangkan lebih lanjut.

\section{SARAN}

Walaupun dalam penelitian pengembangan ini telah didapatkan kenyataan bahwa Media Interaktif Fisika Alat Ukur Listrik menggunakan model Assure ini berhasil meningkatkan prestasi belajar siswa (dengan peningkatan $11,13 \%$ ) namun tak puas sampai disini, dirasakan masih ada banyak kekurangan dalam penelitian pengembangan ini. Untuk itu dimohon kritik dan saran yang bersifat membangun guna meningkatkan prestasi siswa dengan lebih baik lagi. 
Akhirnya dihimbau kepada para pembaca/pengguna hasil pengembangan ini untuk ikut melakukan pengembangan serupa demi meningkatkan mutu pendidikan di Indonesia pada umumnya dan khususnya untuk meningkatkan mutu pendidikan di sekolah masing-masing.

\section{UCAPAN TERIMA KASIH}

Atas terlaksananya penelitian ini mulai dari awal hingga akhir, maka penulis menyampaikan rasa terima kasih kepada :

1. Bapak Dr. Suhartono, M.Pd, Kepala Cabang Pendidikan Wilayah Kabupaten dan Kota Blitar yang telah memberikan motivasi penulis untuk melakukan penelitian ini

2. Teman-teman Pengawas SMA di Cabang Pendidikan Wilayah Kabupaten dan Kota Blitar yang telah memberikan dukungan moral pada penulis untuk melakukan penelitian ini

3. Bapak Drs. Heru Wuryanto, Ketua MGMP Fisika SMA Kabupaten Blitar yang selalu mendampingi penulis dalam kegiatan di MGMP Canag Pendidikan Wilayah Kabupaten dan Kota Blitar yang telah memberikan motivasi penulis untuk melakukan penelitian ini

4. Bapak Gatot Wiyono, S.Pd, M.Pd, Kepala SMA Negeri 1 Garum yang telah memberikan tempat dan kesempatan bagi penulis untuk melakukan uji coba

5. Guru pengajar Fisika yang telah mendampingi penulis dalam melasanakan kegiatan di SMA Negeri 1 Garum

\section{DAFTAR PUSTAKA}

Arikunto, S. (2006). Prosedur penelitian suatu pendekatan praktik . Jakarta: Rineka Cipta.

Arsyad, Azhar. (2002). Media Pembelajaran, Divisi Buku Perguruan Tinggi. Jakarta: P.T. Raja Grafindo Persada, Rajawali Press.

Bintas, J. \& Gelibolu, M. F. (2010). The evaluation of introduction level computer- assisted symbolic logic based on realistic mathematcs education and guided discovery learning approach. International Journal Of Instructional Technology And Distance Learning. 7(2). $61-71$.

Degeng, Sudana. (2005). Pengaruh Teknologi Terhadap Peningkatan Sumber Daya Manusia. Surabaya : Garden Palace Hotel.

Gagne, M. R., Briggs, J.L. \& Wagner, W. W. (1992). Principles of Instructional

Gall, M. D., Gall, J. P \& Borg, W. R. (2003). Education research: An introduction, $7^{\text {th }}$ Eddition. Boston: Allyn \& Bacon.

Kemahyasa. (2012). Pengembangan Multimedia Interaktif Menggunakan Model Borg and Gall. Jurnal Pascasarjana Undiksha Vol 1, No 2 (2012). Singaraja 
Kemp, JE. (1985). The Intructional Design Process. New York : Harper \& Row Publisher, Inc.

Peraturan Pemerintah. No 19 Tahun 2005. Bab I Ayat 6 Tentang Standar Proses Pendidikan Nasional Indonesia. Jakarta: Kementerian Pendidikan Nasional RI

Smaldino, S. E., Lowther, D. L \& Russell, J. D. (2008). Istructional teknology \& media for learning: Teknologi pembelajaran dan media untuk balajar (Terjemahan) Edisi Kesembilan. Jakarta: Kencana. 